SCIENTIFIC REPORT

\title{
The efficacy of sirolimus in the treatment of patients with refractory uveitis
}

\author{
V A Shanmuganathan, E M Casely, D Raj, R J Powell, A Joseph, W M Amoaku, H S Dua
}

Br J Ophthalmol 2005;89:666-669. doi: 10.1136/bjo.2004.048199

Aims: To determine the efficacy of sirolimus in the treatment of patients with severe non-infectious uveitis.

Methods: Eight patients with severe non-infectious uveitis were recruited to an open study. Inclusion criteria were limited to patients whose disease was not controlled with at least two or more separate steroid sparing immunosuppressants (either because of unacceptable side effects or ineffectiveness of the drug) or who required regular doses of corticosteroids either as high dose systemic or orbital floor injections in order to control their disease. Intraocular inflammation, visual acuity, symptoms, corticosteroid burden, drug toxicity, and side effects were monitored.

Results: Sirolimus therapy was effective in five of the eight patients, all of whom had their dose of corticosteroids reduced or discontinued. Treatment in three patients was considered a failure as it caused intolerable side effects and/ or failed to control the uveitis. Side effects were common and were typically gastrointestinal or cutaneous in nature. The severity of symptoms was dose dependent in most cases and occurred at trough blood levels above $25 \mathrm{ng} / \mathrm{ml}$.

Conclusion: Sirolimus is an effective and potent immunosuppressive treatment in the majority of patients with noninfectious uveitis and can reduce the need for long term supplementary corticosteroid therapy. Further studies are required to establish the long term efficacy and safety of sirolimus alone or in combination with other steroid sparing immunosupressants.

S evere non-infectious uveitis is a serious cause of ocular morbidity ${ }^{1}$ and systemic corticosteroids are typically used in the acute stage when local steroid therapy does not control the inflammation. The long term use of systemic corticosteroids to treat chronic disease is problematic because of its adverse side effects ${ }^{2}$ but the advent of steroid sparing immunosuppressive agents has greatly improved the treatment options that are available. However, there is still a subgroup of patients with severe disease recalcitrant to established therapies. These patients are dependent on additional high doses of systemic steroids in order to control or treat exacerbations of their disease and we have a cohort of these patients who attend our ocular immunology clinic. The purpose of this study was to assess the efficacy of a novel immunosuppressant sirolimus (Rapamune, Wyeth Pharmaceuticals, Maidenhead, Berks, UK) in these patients with the view not only to control inflammation but to reduce their corticosteroid burden.

\section{METHODS}

Following informed consent patients attending a specialist combined ophthalmology and immunology clinic were recruited into this open study. Inclusion was limited to patients who had a non-infectious uveitis not controlled with at least two or more separate steroid sparing immunosuppressants (either because of unacceptable side effects or ineffectiveness of the drug) or who required supplementary high dose corticosteroids (systemic or orbital floor injections) in order to control their disease.

Each patient was assessed both ophthalmologically and systemically. Baseline observations included blood pressure, weight, urinalysis, full blood count, urea and electrolytes, liver function tests, $\mathrm{C}$ reactive protein, and a fasting cholesterol. On commencement of treatment these parameters were regularly monitored.

Initially a regimen consisting of a single loading dose of $6 \mathrm{mg}$ sirolimus followed by $2 \mathrm{mg}$ daily, rising in increments to achieve satisfactory drug levels was followed. However, this process was too slow in achieving the required levels for our initial patients and so we started with $4 \mathrm{mg}$ daily increasing by increments of $2 \mathrm{mg}$ as determined by disease activity and trough blood levels. Sirolimus trough levels were measured every 4 weeks once stable drug levels were reached.

Success was defined in this study by one or more of the following parameters: an improvement of two or more lines of Snellen visual acuity, symptomatic improvement (that is, reduction subjectively in the number of floaters, pain, or photophobia), reduction in the number of inflammatory cells by binocular indirect ophthalmoscopy (BIO) as graded by two ophthalmologists (VAS and DR) according to an established uveitis scoring system, ${ }^{3}$ regression of vasculitis, and a reduction in the amount of corticosteroids required for disease control.

\section{RESULTS}

The patient characteristics, previous immunosuppression, doses of sirolimus used, and clinical outcomes are summarised in tables 1 and 2. A total of eight patients with severe non-infectious uveitis were treated with sirolimus, all of whom had a longstanding history of chronic uveitis with multiple recurrences. Three of these patients had an underlying diagnosis of Behçet's syndrome, one had presumed sarcoidosis, and the other four had idiopathic uveitis. The follow up time ranged from 26 to 60 weeks (median 52 weeks). Three patients were considered to have failed on the treatment. In case 1 there was an initial improvement in ocular inflammation and symptoms but on tapering the dose the disease relapsed. Higher doses of sirolimus did not control the uveitis and the patient experienced significant side effects, notably severe abdominal pains with deranged liver function tests which returned to normal on lowering the dose. Control of the disease has yet to be fully regained and he is currently on combination therapy.

Abbreviations: $\mathrm{BIO}$, binocular indirect ophthalmoscopy; $\mathrm{CMO}$, cystoid macular oedema 


\begin{tabular}{|c|c|c|c|c|c|c|}
\hline $\begin{array}{l}\text { Case No, } \\
\text { age, sex }\end{array}$ & Diagnosis & $\begin{array}{l}\text { Relevant history before } \\
\text { treatment }\end{array}$ & $\begin{array}{l}\text { Follow up } \\
\text { (weeks) }\end{array}$ & Previous treatment & $\begin{array}{l}\text { Maximum/ } \\
\text { current dose } \\
\text { of sirolimus }\end{array}$ & $\begin{array}{l}\text { Side effects of } \\
\text { sirolimus therapy }\end{array}$ \\
\hline $1,31, M$ & $\begin{array}{l}\text { Anterior and } \\
\text { intermediate uveitis }\end{array}$ & $\begin{array}{l}\text { Episodes of CMO treated with } \\
\text { orbital floor steroids. History of } \\
\text { steroid induced raised intraocular } \\
\text { pressure }\end{array}$ & 52 & $\begin{array}{l}\text { TAC, } \\
\text { depomedrone, } \\
\text { orbital floor } \\
\text { injections }\end{array}$ & $8 \mathrm{mg} / 4 \mathrm{mg}$ & $\begin{array}{l}\text { Acne, abdominal } \\
\text { pain, deranged liver } \\
\text { function tests }\end{array}$ \\
\hline $2,37, M$ & Panuveitis & & 52 & CYC, MMF, TAC & $10 \mathrm{mg} / 5 \mathrm{mg}$ & $\begin{array}{l}\text { Recurrent chest } \\
\text { infections }\end{array}$ \\
\hline $3,39, \mathrm{~F}$ & $\begin{array}{l}\text { Panuveitis } \\
\text { (unilateral) }\end{array}$ & $\begin{array}{l}\text { Right eye vision reduced as a } \\
\text { result of macular scarring } \\
\text { secondary to chronic CMO. } \\
\text { Repeated episodes of painful } \\
\text { uveitis }\end{array}$ & 52 & $\begin{array}{l}\text { CYC, MMF, TAC, } \\
\text { IV MP }\end{array}$ & $8 \mathrm{mg} / 2 \mathrm{mg}$ & Erythema nodosum \\
\hline $4,30, M$ & $\begin{array}{l}\text { Sarcoidosis, } \\
\text { posterior uveitis }\end{array}$ & $\begin{array}{l}\text { Repeated episodes of vitreous } \\
\text { haemorrhage secondary to } \\
\text { neovascularisation. Episodes of } \\
\text { CMO treated with oral } \\
\text { corticosteroids }\end{array}$ & 40 & TAC, MMF & $4 \mathrm{mg} / \mathrm{OARx}$ & Nausea \\
\hline $5,46, F$ & $\begin{array}{l}\text { Intermediate and } \\
\text { posterior uveitis }\end{array}$ & $\begin{array}{l}\text { Right eye vision reduced as a } \\
\text { result of macular scarring } \\
\text { secondary to chronic CMO. } \\
\text { Episodes of CMO in left good eye } \\
\text { treated with increased doses of } \\
\text { oral corticosteroids. At } \\
\text { commencement of trial persisting } \\
\text { mild CMO in left eye }\end{array}$ & 60 & MMF, TAC, INF & $\begin{array}{l}10 \mathrm{mg} / 0 \mathrm{mg} \text { (treatment } \\
\text { withdrawn) }\end{array}$ & $\begin{array}{l}\text { Breast oedema and } \\
\text { scleroderma-like } \\
\text { changes in the feet }\end{array}$ \\
\hline $6,44, M$ & $\begin{array}{l}\text { Behçet's syndrome, } \\
\text { posterior uveitis } \\
\text { and vasculitis }\end{array}$ & & 60 & CYC, AZA, TAC & $5 \mathrm{mg} / \mathrm{OARx}$ & $\begin{array}{l}\text { Myagia in legs/ } \\
\text { painful feet in dorsal } \\
\text { region }\end{array}$ \\
\hline $7,45, M$ & $\begin{array}{l}\text { Behçet's syndrome. } \\
\text { Posterior uveitis } \\
\text { and vasculitis }\end{array}$ & $\begin{array}{l}\text { Left optic atrophy secondary to } \\
\text { optic nerve ischaemia. Right eye } \\
\text { vision reduced because of old } \\
\text { maculopathy. Marked systemic } \\
\text { symptoms of Behçet's syndrome }\end{array}$ & 52 & CYC, TAC & $8 \mathrm{mg} / 6 \mathrm{mg}$ & Seborrhoeic dermatitis \\
\hline $8,30, F$ & $\begin{array}{l}\text { Behçet's syndrome, } \\
\text { posterior uveitis } \\
\text { and vasculitis }\end{array}$ & $\begin{array}{l}\text { Right eye vision lost because of } \\
\text { refinal arterial occlusion }\end{array}$ & 26 & $\begin{array}{l}\text { CYC, Metho, AZA, } \\
\text { TAC, INF, IV MP }\end{array}$ & $12 \mathrm{mg} / 4 \mathrm{mg}$ & $\begin{array}{l}\text { Eczematous rash and } \\
\text { severe headaches }\end{array}$ \\
\hline
\end{tabular}

CMO, cystoid macular oedema; CYC, cyclosporin; TAC, tacrolimus; INF, infliximab; AZA, azathioprine; Metho, methotrexate; IV MP, intravenous methylprednisolone; MMF, myclophenolate mofetil; OARx, off all treatment.

Treatment in case 5 was stopped as soon as the sclerodermatous-like changes in the foot appeared even though there was an improvement in BIO scores. Case 8 continued to have episodic vasculitis which affected the macula and resulted in transient loss of vision. This required "rescue" courses of high dose intravenous methylprednisolone. Full control of these vasculitic episodes was not achieved despite higher doses of sirolimus (12 mg) and were accompanied by unacceptable side effects. In five of the eight patients there was an improvement as adjudged by the above criteria. All of these five patients had their level of corticosteroids reduced to under $10 \mathrm{mg}$ without compromising the control of intraocular inflammation or symptoms.

\section{DISCUSSION}

Sirolimus was originally developed as an antibiotic ${ }^{4}$ after being isolated from the fungus Streptomyces hygroscopicus. Its potential as an immunomodulatory agent is now established for the prevention of allograft rejection following solid organ transplantation. ${ }^{5}{ }^{6}$ Recently it has been used in sirolimus eluting stents in patients with coronary artery disease, ${ }^{7}$ as it has also been shown to possess an antiproliferative effect on smooth muscle cells and on arterial intimal thickening. ${ }^{8}$

Sirolimus is like cyclosporin and tacrolimus as it is an inhibitor of $\mathrm{T}$ cell activation-it binds to intracellular receptors known as immunophilins. However, it differs from cyclosporin and tacrolimus in that it targets a unique serinethreonine kinase involved in cell signalling. Hence, it functions as non-calcineurin inhibitor of T cells. ${ }^{9}$ It has additional immunomodulatory effects including the inhibition of IL-2 dependent and independent proliferation of B lymphocytes. ${ }^{10}$ Sirolimus has been shown to reduce inflammation in animal models of experimental autoimmune uveitis, albeit in combination with cyclosporin or tacrolimus. ${ }^{11}{ }^{12}$ Hence there were appropriate studies to allow a trial in these patients with treatment resistant uveitis.

Our initial data are promising as five out of the eight patients were deemed to have successful treatment results as determined by our criteria. We were encouraged by the stabilisation of disease and reduction of inflammation without the need for high dose systemic corticosteroids seen in most of our cases. In two patients (cases 4 and 6) the treatment has not only led to a striking improvement in symptoms but the patients have been tapered off all treatment (including sirolimus) and their disease is currently in remission. We speculate that this phenomenon may be related to sirolimus induction of $\mathrm{T}$ cell clonal anergy which has been demonstrated in vivo. ${ }^{13}$ Sirolimus is also likely to be anti-angiogenic. Interestingly, as far back as 1995, Olsen et al showed that rats receiving sirolimus following orthotopic allogenic corneal grafts had reduced amounts of corneal neovascularisation. ${ }^{14}$ More recently Guba and colleagues have elegantly demonstrated the anti-VEGF (vascular endothelial growth factor) activity of sirolimus in a murine tumour model. ${ }^{15}$ This mode of action offers an explanation for the marked clinical improvement in case 4 where there was a dramatic regression of neovascularisation.

The side effects experienced by our patients were mostly dermatological and gastrointestinal in nature. Of the blood tests that were monitored mild increases in serum cholesterol 
Table 2 Clinical outcome of patients treated with sirolimus

\begin{tabular}{|c|c|c|c|c|c|c|}
\hline $\begin{array}{l}\text { Case } \\
\text { No }\end{array}$ & $\begin{array}{l}\text { Snellen visual } \\
\text { acuity } \\
\text { pretreatment }\end{array}$ & $\begin{array}{l}\text { Snellen visual } \\
\text { acuity post- } \\
\text { treatment }\end{array}$ & $\begin{array}{l}\text { Intraocular } \\
\text { inflammation } \\
\text { BIO score RE/LE } \\
\text { pretreatment }\end{array}$ & $\begin{array}{l}\text { Intraocular } \\
\text { inflammation } \\
\text { BIO score } \\
\text { RE/LE } \\
\text { post-treatment }\end{array}$ & $\begin{array}{l}\text { Pretreatment } \\
\text { prednisolone } \\
\text { dose/current } \\
\text { prednisolone } \\
\text { dose }\end{array}$ & Clinical outcome \\
\hline 1 & $6 / 6,6 / 9$ & $\begin{array}{l}6 / 5+3,6 / \\
6+3\end{array}$ & 01 & 12 & $40 \mathrm{mg} / 10 \mathrm{mg}$ & $\begin{array}{l}\text { Treatment failure } \\
\text { Initial control of inflammation followed by } \\
\text { relapse on tapering treatment requiring higher } \\
\text { doses of sirolimus with intolerable side effects } \\
\text { Current medication: tacrolimus, prednisolone } \\
\text { and sirolimus }\end{array}$ \\
\hline 2 & $6 / 18,6 / 12$ & $6 / 9,6 / 9$ & 33 & 00 & $40 \mathrm{mg} / 6 \mathrm{mg}$ & Symptom improvement: reduction of floaters \\
\hline 3 & $6 / 36,6 / 4$ & $6 / 36,6 / 4$ & 10 & 00 & Intermittent IV MP/O mg & $\begin{array}{l}\text { Symptom improvement: reduction in pain and } \\
\text { photophobia }\end{array}$ \\
\hline 4 & $6 / 6+1,6 / 12$ & $6 / 5-1,6 / 9$ & 11 & 00 & $30 \mathrm{mg} / 0 \mathrm{mg}$ & $\begin{array}{l}\text { Reduction in vasculitis and regression of } \\
\text { neovascularisation }\end{array}$ \\
\hline 5 & $1 / 60,6 / 18$ & $1 / 60,6 / 9$ & 12 & 00 & $40 \mathrm{mg} / 15 \mathrm{mg}$ & $\begin{array}{l}\text { Treatment failure } \\
\text { Despite reduction of inflammation mild CMO } \\
\text { persists. Treatment withdrawn due to side effects } \\
\text { Current medication: tacrolimus and oral } \\
\text { corticosteroids }\end{array}$ \\
\hline 6 & $6 / 5,6 / 9$ & $6 / 5,6 / 5$ & 02 & 00 & $\begin{array}{l}50 \mathrm{mg} \text { reducing to } \\
20 \mathrm{mg} / 0 \mathrm{mg}\end{array}$ & Symptom improvement: reduction in pain \\
\hline 7 & $6 / 18, H M$ & $6 / 18, H M$ & 00 & 00 & $15 \mathrm{mg} / 7.5 \mathrm{mg}$ & $\begin{array}{l}\text { Regression of vasculitis with no further flare ups } \\
\text { Marked improvement in systemic symptoms of } \\
\text { Behçet's syndrome } \\
\text { Regression of vasculitis with no further flare ups }\end{array}$ \\
\hline 8 & $\mathrm{HM}, 6 / 12$ & $\mathrm{HM}, 6 / 12$ & 22 & 11 & $\begin{array}{l}\text { Intermittent IV MP/6 mg } \\
\text { and pulsed IV MP }\end{array}$ & $\begin{array}{l}\text { Treatment failure } \\
\text { Continuing episodes of vasculitis leading to } \\
\text { transient vision loss requiring repeated IV MP } \\
\text { Currently on tacrolimus, prednisolone, and } \\
\text { sirolimus }\end{array}$ \\
\hline
\end{tabular}

were also observed. We noted that these side effects could be eliminated or minimised on dose reduction after the initial loading period. Fortunately we did not observe any of the reported serious adverse effects of sirolimus such as deep vein thrombosis and thrombocytopenia. Nevertheless, in three patients where the treatment was considered a failure also experienced intolerable side effects. The frequency and severity of adverse effects occurred at drug trough levels greater than $25.0 \mathrm{ng} / \mathrm{ml}$ and this level remains at the upper end of the therapeutic range. This is $5 \mathrm{ng} / \mathrm{ml}$ higher than the upper range suggested for renal transplantation. ${ }^{16}$ Thus, close monitoring and awareness of potential side effects are critical for patients to be started on this drug.

The advances in our understanding of the immune system has resulted in an increase in the number of therapeutic options available for the treatment of severe uveitis. The use of newer agents such as myclophenolate mofetil, daclizumab, infliximab, and campath-1-H to treat ocular inflammatory diseases has recently been reported with some success. ${ }^{17-20}$ Our experience suggests that sirolimus can be added to this list. However, several key questions remain unanswered: What are the long term effects of these drugs on the immune system? Is there any way to predict which patients are likely to respond to which treatment? Which treatment or combination of treatments is the most effective? The preliminary reports of the newer agents should hopefully be the catalyst for randomised control studies that are needed in order to formulate an evidence base for the best treatment of severe recalcitrant non-infectious uveitis.

We conclude that the management of patients with severe uveitis who do not respond to first line systemic treatment is challenging. Our initial experience with sirolimus demonstrates its effectiveness in the majority of patients with refractory non-infectious uveitis by not only controlling disease activity but also reducing the long term steroid burden.

\section{Authors' affiliations}

V A Shanmuganathan, A Joseph, W M Amoaku, H S Dua, Department of Ophthalmology, Queens Medical Centre, Nottingham, UK

E M Casely, R J Powell, Clinical Immunology Unit, Queens Medical Centre, Nottingham, UK

Correspondence to: H S Dua, Division of Ophthalmology and Visual Science, B Floor, Eye and ENT Centre, Queens Medical Centre, Nottingham NG7 2UH, UK; Harminder.Dua@nottingham.ac.uk

Accepted for publication 16 September 2004

\section{REFERENCES}

1 Rothova A, Suttorp-van Schulten MS, Frits Treffers W, et al. Causes and frequency of blindness in patients with intraocular inflammatory disease. Br J Ophthalmol 1996;80:332-6.

2 Stanbury RM, Graham EM. Systemic corticosteroid therapy-side effects and their management. Br J Ophthalmol 1998;82:704-8.

3 Ben Ezra D, Forrester JV, Nussenblat RB, et al. Uveitis scoring system. Berlin: Springer-Verlag, 1991:1-13.

4 Vezina C, Kudelski A, Sehgal SN. Rapamycin (AY-22,989), a new antifungal antibiotic. I. Taxonomy of the producing streptomycete and isolation of the active principle. J Antibiot (Tokyo) 1975;28:721-6.

5 Dupont $P$, Warrens AN. The evolving role of sirolimus in renal transplantation. Q J Med 2003;96:401-9.

6 Radovancevic B, Vrtovec B. Sirolimus therapy in cardiac transplantation. Transplant Proc 2003;35(Suppl):171S-176S.

7 Moses JW, Leon MB, Popma JJ, et al. Sirolimus-eluting stents versus standard stents in patients with stenosis in a native coronary artery. N Engl J Med 2003;349:1315-23.

8 Gregory CR, Huie P, Shorthouse R, et al. Rapamycin inhibits arterial intimal thickening caused by both alloimmune and mechanical injury. Its effect on cellular, growth factor, and cytokine response in injured vessels. Transplantation 1993;55:1409-18.

9 Kirken RA, Wang YL. Molecular actions of sirolimus: sirolimus and mTor. Transplant Proc 2003;35(Suppl):227S-230S.

10 Aagaard-Tillery KM, Jelinek DF. Inhibition of human B lymphocyte cell cycle progression and differentiation by rapamycin. Cell Immunol 1994:156:493-507.

11 Ikeda E, Hikita N, Eto K, et al. Tacrolimus-rapamycin combination therapy for experimental autoimmune uveoretinitis. Jpn J Ophthalmol 1997;41:396-402. 
12 Martin DF, DeBarge LR, Nussenblatt RB, et al. Synergistic effect of rapamycin and cyclosporin $A$ in the treatment of experimental autoimmune uveoretinitis. $\mathrm{J}$ Immunol 1995; 154:922-7.

13 Powell JD, Lerner CG, Schwartz RH. Inhibition of cell cycle progression by rapamycin induces $\mathrm{T}$ cell clonal anergy even in the presence of costimulation. J Immunol 1999;162:2775-84.

14 Olsen TW, Benegas NM, Joplin AC, et al. Rapamycin inhibits corneal allograft rejection and neovascularization. Arch Ophthalmol 1994:112:1471-5.

15 Guba M, Von Breitenbuch P, Steinbauer M, et al. Rapamycin inhibits primary and metastatic tumor growth by antiangiogenesis: involvement of vascular endothelial growth factor. Nat Med 2002;8:128-35.
16 Masterson $\mathbf{R}$, Leikis M, Perkovic $\mathrm{V}$, et al. Sirolimus: a single center experience in combination with calcineurin inhibitors. Transplant Proc 2003;35(Suppl):99S-104S.

17 Lau CH, Comer M, Lightman S. Long-term efficacy of mycophenolate mofetil in the control of severe intraocular inflammation. Clin Experiment Ophthalmol 2003;31:487-91.

18 Papaliodis GN, Chu D, Foster CS. Treatment of ocular inflammatory disorders with daclizumab. Ophthalmology 2003;110:786-9.

19 Joseph A, Raj D, Dua HS, at al. Infliximab in the treatment of refractory posterior uveitis. Ophthalmology 2003;110:1449-53.

20 Dick AD, Meyer $\mathrm{P}$, James $\mathrm{T}$, et al. Campath-1H therapy in refractory ocular inflammatory disease. Br J Ophthalmol 2000;84:107-9.

\section{Get published within days of acceptance with BJO}

We are delighted to announce that the British Journal of Ophthalmology launched a "publish ahead of print" programme in March 2005. Selected papers are fast tracked and published online months before they appear in the print journal.

Papers of more significance to the international ophthalmology community are published within days of acceptance. The first published article is the raw accepted manuscript; edited and typeset versions are also published as soon as they are available.

In addition to being available on BJO Online, the publish ahead of print articles are searchable through PubMed/Medline - establishing primacy for your work. They are linked from the BJO Online home page.

The BJO's publish ahead of print programme is unique among the major ophthalmology journals - to take advantage of this service submit your papers to the British Journal of Ophthalmology using our online submission and review system Bench $>$ Press (http://submitbjo.bmijournals.com). For further information contact the editorial office (US office choył@itsa.ucf.edu or the UK office anne.williams@bristol.ac.uk). 